\title{
Efek Posisi Orthopneic Terhadap Fungsi Pernafasan: Systematic Review
}

\author{
Roby Rahmadi Akbar', Muh Thohar Arifin², Nana Rochana ${ }^{3}$ \\ ${ }^{1}$ Mahasiswa Magister Keperawatan, Fakultas Kedokteran, Universitas Diponegoro, Semarang \\ Email: obeedakhbar47@gmail.com \\ ${ }^{2}$ Fakultas Kedokteran, Universitas Diponegoro \\ ${ }^{3}$ Departemen Ilmu Keperawatan, Fakultas Kedokteran, Universitas Diponegoro, Semarang
}

\begin{abstract}
Abstrak. Gangguan fungsi pernafasan merupakan masalah yang sering muncul pada pasien Penyakit Paru Obstruktif Kronis (PPOK). Posisi orthopneic adalah intervensi nonfarmakologi yang dapat diberikan pada pasien PPOK. Akan tetapi, sejauh ini belum cukup bukti tentang pengaruh posisi orthopneic terhadap fungsi pernafasan karena outcome yang berbeda-beda. penelitian ini bertujuan untuk mengetahui pengaruh posisi orthopneic terhadap fungsi pernafasan pada pasien PPOK. Kriteria inklusi pada review ini adalah: studi eksperimental, pasien dewasa dengan PPOK derajat sedang sampai berat. Adapun keriteria ekslusi adalah pasien PPOK dengan ventilator dan penelitian pada orang sehat. Pencarian literatur menggunakan sistem database EBSCO, SCOPUS, Pubmed, SinceDirect dan Google Scholar dari tahun 2008 sampai 2019, berbahasa Inggris dan Indonesia. Hasil analisis 8 artikel didapatkan bahwa posisi orthopnneic efektif dalam meringankan atau menurunkan sensasi dispnea pada pasien PPOK dengan rata-rata penurunan (mean pre $=21,87$ dan mean post $=20,80$ ), memaksimalkan fungsi otot aksesoris pernafasan (Sternocleidomastoideus dan Scalenus) (SCM: USit $=4.80$ dan SitAs $=7,92)$ dan (sc : USit= 9.44 dan SitAs= 15,29), meningkatkan volume tidal $(\mathrm{NP}=0,7 \pm 0,2)$ dan $(\mathrm{WAHS}=0,8 \pm 0,3)(\mathrm{Kim}$ et al., 2012) dan meningkatkan nilai APE 27,48\% \pm 14,04\%(Ritianingsih et al., 2011). meningatkan nilai maksimal inspirasi $(64 \pm 22 \mathrm{cmH} 2 \mathrm{O}$ with arm bracing versus $54 \pm 24 \mathrm{cmH} 2 \mathrm{O}$ without arm bracing; $\mathrm{P}=$ 0.0001). dan maksimal ekspirasi (104 \pm 37 cmH2O with arm bracing versus $92 \pm 37$ cmH2O without arm bracing; $p=0.0001)$. Gangguan utama pada pasien PPOK adalah proses ekspirasi yang memanjang akibat adanya obstruksi. Posisi orthopneic memaksimalkan fungsi otot aksesoris pernafasan, sehingga proses inspirasi dan ekspirasi menjadi maksimal.
\end{abstract}

Kata kunci: Fungsi Pernafasan, Posisi Orthopneic, PPOK.

\section{Orthopneic Position Effects on Respiratory Function: Systematic Review}

\begin{abstract}
Impaired respiratory function is a problem that often arises in patients with Chronic Obstructive Pulmonary Disease (COPD). The orthopneic position is a non-pharmacological intervention that can be given to COPD patients. However, so far there is not enough evidence about the effect of orthopneic position on respiratory function due to different outcomes. This study aims to determine the effect of orthopneic position on respiratory function in COPD patients. The inclusion criteria for this review are: experimental studies, adult patients with moderate to severe COPD. The exclusion criteria are COPD patients with ventilators and studies in healthy people. A literature search using the EBSCO, SCOPUS, Pubmed, ScienceDirect, and Google Scholar database systems from 2008 to 2019, in English and Indonesian. The results of the analysis of 8 articles found that the orthopneic position is effective in relieving or decreasing dyspnea sensation in COPD patients with a mean decrease (mean pre $=21.87$ and mean post $=20.80)$, maximizing the function of respiratory accessory muscles (Sternocleidomastoideus and Scalenus) ( SCM: USit $=4.80$ and SitAs $=7.92$ ) and (sc: USit $=9.44$ and Sit $A s=15.29)$, increasing the tidal volume $(N P=0.7+0.2)$ and $(W A H S=0.8+0,3) 7$ and increase the APE value $27.48 \%+14.04 \%$ 5. increase the maximum inspiration value $(64 \pm 22 \mathrm{cmH} 2 \mathrm{O}$ with arm bracing versus $54 \pm 24 \mathrm{cmH} 2 \mathrm{O}$ without arm bracing; $P=0.0001)$. and maximal expiration $(104 \pm 37 \mathrm{cmH} 20$ with arm bracing versus $92 \pm 37 \mathrm{cmH} 20$ without arm bracing; $p=0.0001)$. The main disorder in COPD patients is the process of expiration which is prolonged due to obstruction. The orthopneic position maximizes the function of respiratory accessory muscles so that the process of inspiration and expiration is maximized. Keywords: COPD, Orthopneic Position, Respiratory Function.
\end{abstract}




\section{Pendahuluan}

Penyakit Paru Obstruksi Kronis (PPOK) adalah salah satu penyakit yang mengganggu kebutuhan oksigen dengan menghambat aliran udara pada saluran pernafsan dengan progresif non-reversibel, parsial dan peradangan pada partikel paru (Hinkle and Cheever, 2010). WHO memperkirakan pada awal 2020 prevalensi PPOK akan meningkat dari peringkat 12 ke peringkat 5 didunia. Sekitar $6 \%$ dari jumlah populasi orang dewasa di setiap Negara mengalami PPOK(Singh et al., 2019). Penyakit ini juga merupakan salah satu penyebab morbiditas dan mortalitas yang jumlahnya terus meningkat didunia (Agussalim, 2016).

PPOK sangat mengganggu pada proses ekspirasi di akibatkan oleh obstruksi pada paru-paru dan gangguan pada elastisitas recoil paru.(Hartley, 2018) Manifestasi klinis yang muncul pada pasien PPOK diantaranya adalah dispnea, hipoksemia, hiperkapnia, dan adanya penggunaan otot bantu nafas tambahan serta fase ekspirasi yang memanjang (Ritianingsih et al., 2011). pengaturan posisi tubuh yang tepat terbukti dalam mengatasi permasalah yang dihadapi oleh pasien PPOK (Barbara K. Timby and Nancy E. Smith et al., 2010).

\section{Metode}

Dalam review ini bertujuan untuk menganalisis pengaruh dari posisi orthopneic terhadap fungsi pernafasan dengan kriteri inklusi : studi eksperimental, pasien dewasa, dan pasien PPOK derajat sedang sampai berat. Adapun keriteria ekslusi pada penelitian ini adalah pasien PPOK yang menggunakan ventilator dan penelitian pada orang sehat. Pencarian literatur adalah dengan menggunakan database dan search engine yaitu EBSCO, SCOPUS, Pubmed, SinceDirect dan Google Scholar dari tahun 2008 sampai 2019 dengan kata kunci dalam bahasa inggris: orthopneic Position, forwardLeaning position, forward trunk lean, respiratory function. bahasa Indonesia : posisi
Posisi orthopneic dan latihan nafas merupakan pilihan utama dalam memberikan intervensi terapeutik pada pasien PPOK dalam meringankan sensaasi dispnea dan meningkatkan fungsi paru. Berdasakan penelitian Song Kim et al pada tahun 2012, posisi orthopneic pada pasien PPOK dapat membantu untuk perbaikan fungsi paru.(Kim et al., 2012) Kekuatan gravitasi dan variasi posisi tubuh terbukti dalam mempengaruhi fungsi otot pernafasan. Salah satu posisi tubuh yang dapat mempengaruhi peningkatan fungsi otot pernafasan adalah posisi orthopneic. Beberapa hasil penelitian posisi orthopneic meningkatkan ventilasi paru, meningkatkan pergerakan otot diafragma dan mengurangi sesasi dispnea pada pasien PPOK (Cavalheri et al., 2010).

Sejauh ini telah banyak penelitian tentang pengaruh posisi orthopneic pada pasien PPOK. Akan tetapi penelitian yang dilakukan memiliki outcome yang yang berbeda-beda terhadap fungsi pernafasan sehingga peneliti melakukan systematic review dari artikel-artikel terkait dengan posisi orthopneic. Review ini bertujuan untuk mengetahui pengaruh posisi orthopneic terhadap fungsi pernafasan pada pasien PPOK.

orthopneic, Posisi Menunduk, Fungsi Pernafasan. selanjutnya peneliti melakukan critical appraisal untuk menganalisis artikel menggunakan JBI (Joanna Briggs Institute). 


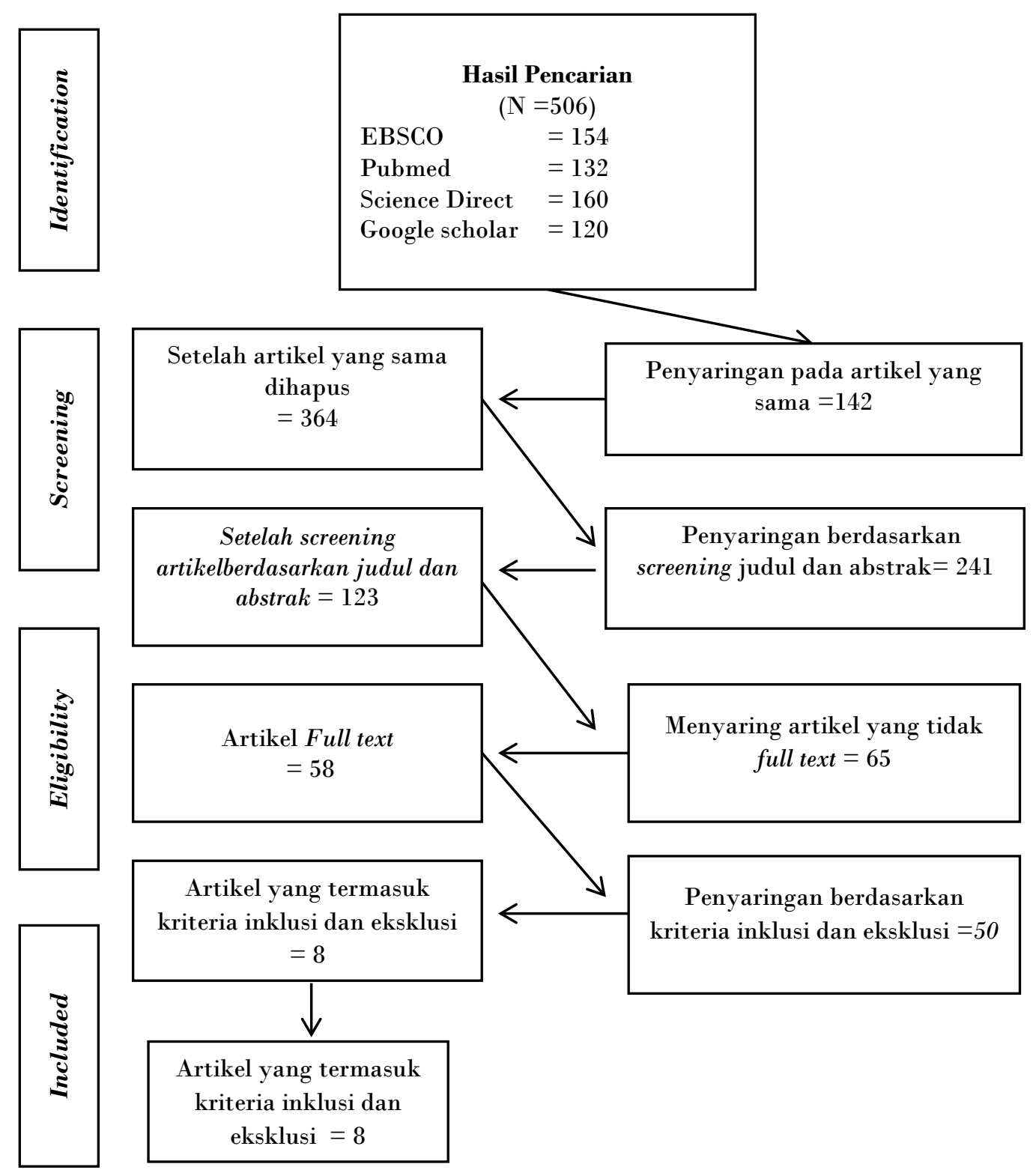

Gambar 1. Hasil pencarian artikel

\section{Hasil Penelitian}

Dari hasil pencarian menggunakan data base dan search engine didapatkan 506 artikel. Setelah itu kami melakukan penghapusan pada artikel yang sama, screening berdasarkan judul dan abstrak, dan artkel yang tidak lengkap sebanyak 448 artikel. Selanjutkanya kami melakukan seleksi berdasarkan kriteria inklusi dan kriteria ekslusi pada 58 artikel dan didapatkan 8 artikel.

Berdasarkan hasil review artikel tentang pengaruh posisi orthopneic terhadap fungsi pernafsan pada pasien COPD didapatkan 3 artikel berbahasa Indonesia dan 5 artikel berbahasa inggris. Dari 8 artikel tidak terdapat artikel yang menggunakan metode RCT (Randomize control trial) sehingga level of evidance semua artikel 
adalah level II. Selanjutnya dilakukan appraisal menggunakan JBI didapatkan 6 artikel dengan kwalitas tinggi dan 2 artikel dengan kualitas baik.

Peneliti mendapatkan hasil bahwa posisi orthopnneic efektif dalam meringankan atau menurunksn sensasi dispnea pada pasien PPOK dengan rata-rata penurunan (mean pre $=21,87$ dan mean post $=20,80)($ Agussalim, 2016), pada penelitian lain penurunan dispnea ( mean pre klp intervensi $=6$ dan post intervensi $=$ $3)($ Maryoto, 2016), $($ pre $=44.31 \pm 22.17$ dan post $=40.08 \pm 23.17)($ Eva Priscilla Manoppo, 2014). Selain itu posisi orthopneic juga memberikan efek memaksimalkan fungsi otot aksesoris pernafsan (Sternocleidomastoideus dan Scalenus) sehingga memaksimalkan fungsi ventilasi dengan nilai mean ( SCM : USit $=4.80$ dan
SitAs $=7,92)$ dan $(\mathrm{sc}:$ USit $=9.44$ dan SitAs $=15,29)$ (Mesquita et al., 2018).

Pergerakan otot-otot pernafasan secara maksimal dapat memperbaiki pola nafas, meningkatkan Volume tidal ( $\mathrm{NP}=$ $0,7 \pm 0,2)$ dan (WAHS $=0,8 \pm 0,3)(\operatorname{Kim}$ et al., 2012) dan meningkatkan nilai APE pada posisi high fowler $25,89 \% \pm 13,70 \%$ dan posisi orthopneic $27,48 \% \quad \pm$ 14,04\%(Ritianingsih et al., 2011). Posisi orthopneic juga memberikan pengaruh terhadap fungsi pernafasan berdasarkan penilaian fungsi faal paru dengan nilai maksimal inspirasi $(64 \pm 22 \mathrm{cmH} 20$ with arm bracing versus $54 \pm 24 \mathrm{cmH} 2 \mathrm{O}$ without arm bracing; $\mathrm{P}=0.0001)$. dan maksimal ekspirasi $(104 \pm 37 \mathrm{cmH} 20$ with arm bracing versus 92 \pm 37 cmH2O without arm bracing; $\mathrm{p}=$ 0.0001)(Cavalheri et al., 2010). 
Tabel. 1 Ekstract Data

\begin{tabular}{|c|c|c|c|c|c|c|}
\hline Peneliti & Tahun & $\begin{array}{l}\text { Junlah } \\
\text { Sampel }\end{array}$ & $\begin{array}{c}\text { Desain } \\
\text { Penelitian }\end{array}$ & Intervensi & Hasil Penelitian & $\begin{array}{c}\text { Level \& } \\
\text { Kuwalitas } \\
\text { Evidence }\end{array}$ \\
\hline Song kim, et al & 2012 & 24 & $\begin{array}{c}\text { Quasi } \\
\text { eksperiment }\end{array}$ & $\begin{array}{l}\text { Sitting postures : (neutral } \\
\text { Position) NP, (with Arm } \\
\text { support) WAS dan (with } \\
\text { Arm and Head Support) } \\
\text { WAHS dengan latihan } \\
\text { nafas (Quiet Breathing) } \\
\text { QB dan (Pursed-lips } \\
\text { breathing) r PLB. } \\
\text { Intervensi diberikan } \\
\text { selama } 5 \text { menit. }\end{array}$ & $\begin{array}{l}\text { Latihan nafas dengan PLB dengan posisi duduk } \\
\text { WAS (posisi orthopneic) dapat meningkatkan } \\
\text { volume tidal dan menurunkan RR dan } \\
\text { meningkatkan volume tidal pada pasien PPOK } \\
\text { dengan nilai. (Posisi orthopneic) WAHS } \\
\text { meningkatkan aktivitas otot pernafasan pada } \\
\text { pasien PPOK dengan nilai }(\text { Mean } \pm \mathrm{SD}=204 \pm 89) \\
\text { dan NP }(100.0 \pm 0) \text {. } \\
\text { Volume tidal }(\mathrm{NP}=0,7 \pm 0,2) \text { dan (WAHS } \\
=0,8 \pm 0,3) \text {. Respirasi rate }(\mathrm{NP}=18,1 \pm 3,0) \text { dan } \\
(\text { WAHS }=16,5 \pm 2,1) .\end{array}$ & $\begin{array}{l}\text { Level II } \\
\text { dengan } \\
\text { kuwalitas } \\
\text { tinggi }\end{array}$ \\
\hline Agussalim & 2013 & 15 & $\begin{array}{c}\text { Quasi } \\
\text { eksperiment }\end{array}$ & $\begin{array}{l}\text { Posisi high fowler dan } \\
\text { orthopneic. } \\
\text { dilakukan selama } 15 \text { menit. }\end{array}$ & $\begin{array}{l}\text { Posisi orthopneic dan high fowler dapat berpengaruh } \\
\text { positif terhadap Apnea pada pasien COPD dengan } \\
\text { nilai (mean pre = } 21,87 \text { dan mean post }=20,80 \\
\text { orthopneic position), dan (mean pre }=22,33 \text { dan } \\
\text { mean post }=21,13 \text { hight fowler position) akan } \\
\text { tetapi tidak ada perbedaan yang signifikan efek } \\
\text { yang dihasilkan pada kedua posisi. }\end{array}$ & $\begin{array}{l}\text { Level II } \\
\text { dengan } \\
\text { kuwalitas } \\
\text { tinggi }\end{array}$ \\
\hline Mesquita, et al & 2018 & 35 & $\begin{array}{c}\text { Quasi } \\
\text { eksperiment }\end{array}$ & $\begin{array}{l}\text { (Posisi bediri tegak dan } \\
\text { duduk tegak) }\end{array}$ & $\begin{array}{l}\text { Posisi berdiri menunduk dan duduk menunduk } \\
\text { (orthopneic) lebih baik dalam mengaktifkan atau } \\
\text { memaksimalkan fungsi otot aksesoris pernafasan } \\
\text { sehingga memaksimalkan fungsi ventilasi } \\
\text { dibandingkan dengan posisi berdiri tegak dan } \\
\text { duduk tegak pada pasien PPOK dengan nilai ( SCM } \\
\text { : USit }=4.80 \text { dan SitAs }=7,92) \text { dan ( } \text { sc }: \text { USit }=9.44 \\
\text { dan SitAs }=15,29 \text { ). }\end{array}$ & $\begin{array}{l}\text { Level II } \\
\text { dengan } \\
\text { kuwalitas } \\
\text { tinggi }\end{array}$ \\
\hline $\begin{array}{l}\text { Cavalheri, et } \\
\text { al }\end{array}$ & 2009 & 20 & $\begin{array}{c}\text { Quasi } \\
\text { eksperiment }\end{array}$ & $\begin{array}{lr}\text { Posisi menunduk } & \text { berdiri } \\
\text { dengan tanga } & \text { ditekuk. } \\
\text { Intervensi } & \text { diberikan } \\
\text { selama } 2 \text { menit. } & \end{array}$ & $\begin{array}{l}\text { Posisi berdiri menunduk dapat meningkatkan } \\
\text { fungsi diafragma dan mereduksi tekanan otot } \\
\text { abdomen dan menekuk tangan kedalam membantu } \\
\text { otot asesoris pernafasan menjadi efektif dinilai dari }\end{array}$ & $\begin{array}{l}\text { Level II } \\
\text { dengan } \\
\text { kuwalitas } \\
\text { tinggi }\end{array}$ \\
\hline
\end{tabular}




\begin{tabular}{|c|c|c|c|c|c|c|}
\hline & & & & & $\begin{array}{l}\text { maksimal inspirasi }(64 \pm 22 \text { cmH } 2 \mathrm{O} \text { with arm } \\
\text { bracing versus } 54 \pm 24 \mathrm{cmH} 2 \mathrm{O} \text { without arm bracing; } \\
\mathrm{P}=0.0001) . \text { dan maksimal ekspirasi }(104 \pm 37 \\
\text { cmH } 2 \mathrm{O} \text { with arm bracing versus } 92 \pm 37 \mathrm{cmH} 2 \mathrm{O} \\
\text { without arm bracing; } p=0.0001) .\end{array}$ & \\
\hline $\begin{array}{l}\text { Ritianingsih } \\
\text { N }\end{array}$ & 2011 & 36 & $\begin{array}{c}\text { Quasi } \\
\text { eksperimen }\end{array}$ & $\begin{array}{l}\text { High fowler position dan } \\
\text { orthopneic } \\
\text { Intervensi } \\
\text { Selama } 15 \text { menit. }\end{array}$ & $\begin{array}{l}\text { Posisi orthopneic dapat meningkatkan fungsi } \\
\text { ventilasi paru klien PPOK lebih baik dibandingkan } \\
\text { posisi high fowler dibuktikan dengan nilai } \\
\text { peningkatan nilai APE pada pasien dengan posisi } \\
\text { orthopneic lebih tinggi dari pada high fowler, } \\
\text { walupun frequensi nafas tidak ada perubahan. } \\
\text { Rerata nilai APE pada posisi high fowler adalah } \\
25,89 \% \pm 13,70 \% \text {, sedangkan pada posisi } \\
\text { orthopneic didapat reratanya } 27,48 \% \pm 14,04 \% \text {. } \\
\text { Perbedaan rerata antara nilai APE pada posisi high } \\
\text { fowler dan orthopneic adalah } 0,16 \text { dengan SD } 2,09 . \\
\text { Hasil uji statistik didapatkan p = } 0,0005 \text {, maka } \\
\text { dapat disimpulkan bahwa ada perbedaan yang } \\
\text { signifikan antara nilai APE pada posisi high fowler } \\
\text { dengan posisi orthopneic. }\end{array}$ & $\begin{array}{l}\text { Level II } \\
\text { dengan } \\
\text { kuwalitas } \\
\text { tinggi }\end{array}$ \\
\hline Maryoto & 2016 & 25 & $\begin{array}{c}\text { Quasi } \\
\text { eksperimen }\end{array}$ & $\begin{array}{l}\text { Posisi semi fowler dengan } \\
\text { natural breathing dan } \\
\text { posisi orthopneic dengan } \\
\text { pursed-limp breathing. } \\
\text { Intervensi dilakukan } \\
\text { selama } 15 \text { menit dalam } \\
\text { waktu } 3 \text { hari. }\end{array}$ & $\begin{array}{l}\text { Posisi orthopneic dengan PLB lebih efektif dari } \\
\text { posisi semi fowler dengan natural breathing dalam } \\
\text { menurunkan dispnea pada pasien PPOK dengan } \\
\text { nilai ( mean pre klp intervensi }=6 \text { dan post } \\
\text { intervensi }=3 \text { ) }\end{array}$ & $\begin{array}{l}\text { Level II } \\
\text { dengan } \\
\text { kuwalitas } \\
\text { baik }\end{array}$ \\
\hline manoppo & 2017 & 25 & $\begin{array}{c}\text { Quasi } \\
\text { eksperimen }\end{array}$ & $\begin{array}{l}\text { Posisi semi fowler dan } \\
\text { posisi } \\
\text { Intervensi orthopneic. } \\
\text { selama } 15 \text { menit. }\end{array}$ & $\begin{array}{l}\text { Posisi orthopneic dan posisi semi fowler efektif } \\
\text { dalam menurunkan dispnea pada pasien PPOK } \\
\text { akan tetapi nilai mean pada posisi orthopneic lebih } \\
\text { besar dari pada posisi semi fowler dengan nilai } \\
\text { perbedaan ( mean difference pada }(\mathrm{HR}=4.80000) \\
(\mathrm{RR}=1.13333,) \text { (skala sesak nafas }=1.0000) \text {. }\end{array}$ & $\begin{array}{l}\text { Level II } \\
\text { dengan } \\
\text { kuwalitas } \\
\text { baik }\end{array}$ \\
\hline $\begin{array}{l}\text { Baysal E, et } \\
\text { al. }\end{array}$ & 2017 & 60 & $\begin{array}{c}\text { Quasi } \\
\text { eksperiment }\end{array}$ & $\begin{array}{l}\text { Posisi orthopneic dan } \\
\text { posisi supine }\end{array}$ & $\begin{array}{l}\text { Hasil penelitian menunjukkan bahwa terjadi } \\
\text { penurunan tingkat dispnea aetelah diberikan }\end{array}$ & $\begin{array}{lr}\text { Level II } \\
\text { dengan }\end{array}$ \\
\hline
\end{tabular}




\begin{tabular}{|l|l|l|l|l|}
\hline & & & & $\begin{array}{l}\text { intervensi posisi orthopneic dengan nilai mean SD } \\
\text { (pre }=44.31 \pm 22.17 \text { dan post }=40.08 \pm 23.17) .\end{array}$ \\
\hline
\end{tabular}

\section{Pembahasan}

Dispnea

Posisi orthopnneic efektif dalam meringankan atau menurunksn sensasi dispnea pada pasien PPOK dengan ratarata penurunan (mean pre $=21,87$ dan mean post $=$ 20,80)(Agussalim, 2016), pada penelitian lain penurunan dispnea ( mean pre klp intervensi $=6$ dan post intervensi $=$ $3)($ Maryoto, 2016), $($ pre $=44.31 \pm 22.17$ dan post $=40.08 \pm$ 23.17)(Eva Priscilla Manoppo, 2014). Dispnea adalah pengalaman subjektif tentang ketidaknyamanan saat bernafas dengan kuwalitas ringan, sedang dan berat(Caroci and Lareau, 2004). Dispnea juga merupakan gejala utama yang terjadi pada pasien dengan gangguan sistem respirasi dan sistem cardiovascular(Berliner et al., 2016). Dispnea pada pasien PPOK terjadi karena adanya obstruksi pada saluran pernafsan sehingga terjadi aliran pernafasan yang buruk yaitu

\section{Otot Pernafasan}

Posisi orthopneic memberikan efek memaksimalkan fungsi otot aksesoris pernafasan (Sternocleidomastoideus dan Scalenus) sehingga memaksimalkan fungsi ventilasi dengan nilai mean ( SCM : USit $=4.80$ dan SitAs $=7,92)$ dan $(\mathrm{sc}:$ USit $=9.44$ dan SitAs $=15,29)($ Mesquita et al., 2018). Pergerakan ketidakmampuan menghebuskan nafas secara penuh dan karbondioksida yang tidak dapat dikeluarkan akan terperangkap didalam paru(A., 2019). Sehingga kadar karbondiaoksida yang ada didalam paru-paru menjadi meningkat(Wysham et al., 2015).

Intervensi pengaturan posisi orthopneic membentuk organ-organ sistem pernafasan menjadi bekerja secara menyeluruh dan maksimal. Posisi ini membentuk otot diafhragma dan otot-otot asesoris pernafasan lainnya berkontaksi dengan makasimal sehingga menyebabkan paru dapat mengembang dengan maksimal(Lee and Han, 2017). Saat paru dapat mengembang dengan maksimal akan membuat tekanan dalam paru menjadi meningkat sehingga tekanan ketika ekspirasi juga akan meningkat dan pengeluaran karbondioksida akan menjadi lebih banyak (Ignatavicius and Workman, 2016; Lewis et al., 2016). 
otot-otot pernafasan secara maksimal sehingga dapat memperbaiki pola nafas, meningkatkan Volume tidal $(\mathrm{NP}=0,7 \pm 0,2)$ dan (WAHS $=0,8 \pm 0,3)($ Kim et al., 2012) dan meningkatkan nilai APE pada posisi high

Posisi orthopneic dapat meningkatkan fungsi diafragma dan mereduksi tekanan otot abdomen. Posisi menekuk tangan kedalam membantu otot asesoris pernafasan menjadi efektif dinilai dari maksimal inspirasi (Cavalheri et al., 2010; Kim et al., 2012; Mesquita et al., 2018). Otot-otot pernafasan pada posisi orthopneic akan terjadi peningkatan seperti pada diafragma dengan cepat bergerak naik dan turun untuk memperbesar dan memperkecil rongga dada. Selain itu, tulang iga akan terelevasi dan terdepresi sehingga berpengaruh memperbesar dan memperkecil diameter anteroposterior rongga dada (Williams, Linda S and Hopper, 2007). Posisi ini memberikan ruang pada diafragma sehingga dapat merenggang sehingga memberikan ruang yang lebih luas pada paru ketika

\section{Fungsi faal paru}

Pergerakan otot-otot pernafasan secara maksimal dapat memperbaiki pola nafas, meningkatkan Volume tidal ( $\mathrm{NP}=$ $0,7 \pm 0,2)$ dan (WAHS $=0,8 \pm 0,3)(\mathrm{Kim}$ et al., 2012) dan meningkatkan nilai APE pada posisi high fowler $25,89 \% \pm 13,70 \%$ dan posisi orthopneic $27,48 \% \quad \pm$ 14,04\%(Ritianingsih et al., 2011). Posisi orthopneic juga memberikan pengaruh terhadap fungsi pernafasan berdasarkan penilaian fungsi faal paru dengan nilai maksimal inspirasi $(64 \pm 22 \mathrm{cmH} 20$ with arm bracing versus $54 \pm 24 \mathrm{cmH} 2 \mathrm{O}$ without arm bracing; $\mathrm{P}=0.0001)$. dan maksimal ekspirasi (104 $\pm 37 \mathrm{cmH} 20$ with arm bracing versus 92 \pm 37 cmH2O without arm bracing; $\mathrm{p}=$ fowler $25,89 \% \pm 13,70 \%$ dan posisi orthopneic 27,48\% \pm 14,04\%(Ritianingsih et al., 2011). Pada posisi tubuh duduk biasa otot-otot aksesoris tidak dapat bekerja dengan maksimal.(Lee and Han, 2017)

inspirasi sehingga oksigen yang masuk menjadi lebih banyak,(Gosselink, 2003) dan sebaliknya pada saat ekspirasi diafragma dapat memberikan tekanan yang lebih besar sehingga tekanan dalam paru meningkat dan meningkatkan efektivitas ekspirasi yang menjadi gangguan utama pada pasien PPOK (Bailey et al., 2013; Ogino et al., 2015). Melemahnya daya tahan dan kekuatan otot inspirasi adalah salah satu gangguan fungsi pernafasan pada pasien PPOK. Meningkatkan fungsi otot pernafasan sangat membantu dalam mengurangi beban pernafasan dan dapat mengurangi sensasi dispnea serta meningkatkan fungsi ventilasi (Ogino et al., 2015). Sehingga sangat penting untuk memberikan intervensi yang dapat meningkatkan kekuatan otot pernafasan.

0.0001)(Cavalheri et al., 2010). Sebagaimana diketahui bahwa gangguan yang terjadi pada pasien PPOK adalah pada fungsi ventilasi karena terjadinya obstruksi pada saluran pernafasan. Hasil pemeriksaan fungsi paru membuktikan adanya perubahan perbaikan yang terjadi pada fungsi ventilasi paru(Education and Society, 2013).

Pada klien PPOK diameter anteroposterior dada akan membesar dikarenakan adanya tahanan udara paru dan terjadi gangguan pada fungsi ventilasi sehingga menyebabkan volume tidal tidak terpenuhi dan nilai APE menurun (Barbara K. Timby and Nancy E. Smith et al., 2010; Lewis et al., 2016). Pergerakan diafragma 
akan menurun dan pergerakan tulang rusuk menjadi tegang sebagai akibat adanya perubahan pada dinding dada, sehingga posisi duduk dengan badan sedikit membungkuk (orthopneic) dapat mempermudah diafragma untuk terangkat, sehingga mempermudah aliran udara (Barbara K. Timby and Nancy E. Smith et al., 2010; Hinkle and Cheever, 2010). Pasien PPOK memiliki fase ekspirasi yang lebih panjang dibandingkan dengan fase inspirasinya, disebabkan oleh adanya obstruksi pada jalan nafas sehingga mengakibatkan volume tidak menjadi tidak terpenuhi dan nilai APE akan menurun(Barbara K. Timby and Nancy E. Smith et al., 2010; Farrell, 2017). Posisi orthopneic merenggangkan otot-otot pernafasan secara maksimal sehingga memberikan ruang yang lebih luas dan tekanan menjadi lebih kuat. Jika tekanan dalam paru meningkat maka proses ekspirasi akan menjadi lebih mudah dan lebih efektif,

\section{Daftar Pustaka}

A., M. S. (2019) 'The effects of positioning and pursed-lip breathing exercise on dyspnea and anxiety status in patients with chronic obstructive pulmonary disease', 9(6), pp. 41-51. doi: 10.5430/jnep.v9n6p41.

Agussalim (2016) 'The Effects of High Fowler and Orthopneic Position in Lung Ventilation; A QuantitativeExperimental Study', 5(2), pp. 20142017.

Bailey, P. H. et al. (2013) 'Best practice in nursing care of dyspnea : The 6 th vital sign in individuals with COPD', 3(1), pp. 108-122. doi: 10.5430/jnep.v3n1p108.

Barbara K. Timby and Nancy E. Smith et al. (2010) Medical-Surgical Nursing. 10 Edition. Wolters Kluwer Health. sehingga volume tidal dapat terpenuhi dan nilai APE akan meningkat (Ignatavicius and Workman, 2016).

\section{Pola Nafas dan Frekuensi Nafas}

Dari hasil penelitian didapatkan bahwa posisi orthopneic memberikan efek positif pada fungsi pernafasan dengan memperbaiki pola nafas dan frekuensi nafas (Cavalheri $e t$ al., 2010; Kim et al., 2012). Salah satu permasalahan pada pasien PPOK adalah tidak efektifnya pola nafas(Caroci and Lareau, 2004). Intervensi keperawatan yang dapat dilakukan adalah pengaturan posisi, dimana posisi ini diberikan bertujuan untuk memberikan atau meningkatkan rasa nyamanan pada pasien sehingga dapat memperbaiki pola nafas pada pasien PPOK (Barbara K. Timby and Nancy E. Smith et al., 2010; Peate, 2013). Ketika pola nafas pasien baik, maka akan memperbaiki frekuensi nafas pasien. Frekuensi nafas normal manusia bervariasi sesuai dengan usia (Hartley, 2018).

Berliner, D. et al. (2016) 'The Differential Diagnosis of Dyspnea'. doi: 10.3238/arztebl.2016.0834.

Caroci, A. D. S. and Lareau, S. C. (2004) 'Descriptors of dyspnea by patients with chronic obstructive pulmonary disease versus congestive heart failure', Heart and Lung: Journal of Acute and Critical Care, 33(2), pp. 102-110. doi: 10.1016/j.hrtlng.2003.11.004.

Cavalheri, V. et al. (2010) 'Effects of arm bracing posture on respiratory muscle strength and pulmonary function in patients with chronic obstructive pulmonary disease', 17(6), pp. 887-891.

Education, C. and Society, A. T. (2013) 'Routine Dyspnea Assessment on Unit Admission', 113(11).

Eva Priscilla Manoppo (2014) 'perbedaan posisi semi fowler dan posisi orthopneic 
terhadap penanganan pasien sesak di RSUP prof. dr. R. D. Kandou Manado'.

Farrell, M. (2017) Smeltzer \&amp; Bares Textbook of Medical-Surgical Nursing. 4th editio. Edited by M. Farrell. new zealand: North Ryde, N.S.W :Lippincott Williams \& Wilkins/Wolters Kluwer Health.

Gosselink, R. (2003) 'Controlled breathing and dyspnea in patients with chronic obstructive pulmonary disease (COPD).', Journal of rehabilitation research and development, 40(5), pp. 2533. doi: 10.1682/JRRD.2003.10.0025.

Hartley (2018) respiratory rate 2: anatomy and physiology of breathing., nursing time.

Hinkle, J. L. and Cheever, K. H. (2010) Brunner \&amp; Suddarth's textbook of medical-surgical nursing.

Ignatavicius, D. D. and Workman, M. L. (2016) 'Medical Surgical Nursing: Patient-Centered Collaborative Care', p. 5111 .

Kim, K. et al. (2012) 'Effects of breathing maneuver and sitting posture on muscle activity in inspiratory accessory muscles in patients with chronic obstructive pulmonary disease', pp. 1-6.

Lee, J. and Han, D. (2017) 'Effect of the trunk forward bending angle in sitting position on slow vital capacity', pp. 2220-2223.

Lewis, S. M. et al. (2016) Medical-surgical nursing : assessment and management of clinical problems.

Maryoto, khasanah suci and (2016) 'efektivitas posisi orthopneic dan pursed lips breathing (PLB) terhadap penururnan keluhan sesak nafas pasien PPOK', 3(1), pp. 44-52.

Mesquita, A. et al. (2018) 'Human Movement Science Forward trunk lean with arm support a ff ects the activity of accessory respiratory muscles and thoracoabdominal movement in healthy individuals', Human Movement Science. Elsevier, 61(July), pp. 167176. doi: 10.1016/j.humov.2018.07.011. Ogino, T. et al. (2015) 'Effects of Arm Bracing on Expiratory Flow Limitation and Lung Volume in Elderly COPD Subjects', 1, pp. 12821287. doi: 10.4187/respcare.03945.

Peate, M. N. and I. (2013) Students, Fundamental of Applied Pathophysiology an essential guide for nursing an healtcare. Second Edi, WILEY-BLACKWELL. Second Edi.

Ritianingsih, N. et al. (2011) "peningkatan fungsi ventilasi paru pada klien penyakit paru obstruksi kronis dengan posisi high fowler dan orthopneic', Journal Keperawatan Indonesia, 14(1), pp. 33-36.

Singh, D. et al. (2019) 'Global Strategy for the Diagnosis, Management, and Prevention of Chronic Obstructive Lung Disease: the GOLD science committee report 2019', The European respiratory journal, 53(5). doi: 10.1183/13993003.00164-2019.

Williams, Linda S and Hopper, P. (2007) Understanding medical-surgical nursing. Third Edit. Philadelphia: F.A. Davis Company. doi: 10.1002/15213773(20010316)40:6<9823::AIDANIE9823>3.3.CO;2-C.

Wysham, N. G. et al. (2015) 'Practical Dyspnea Assessment: Relationship Between the 0 e 10 Numerical Rating Scale and the Four-Level Categorical Verbal Descriptor Scale of Dyspnea Intensity', Journal of Pain and Symptom Management. Elsevier Inc, 50(4), pp. 480-487. doi: 10.1016/j.jpainsymman.2015.04.015. 